\title{
Medical Experiences from a Consular Repatriation and Evacuation Operation from Afghanistan in August 202 1: A Field Report
}

\author{
Karin Hugelius, PhD, RN, RNA; ${ }^{10}$ Lisa Kurland, Prof, PhD, MD²,3
}

1. Faculty of Medicine and Health, Örebro University, Örebro, Sweden

2. Department of Emergency Medicine, Örebro University Hospital, Örebro, Sweden

3. Department of Medical Sciences, Örebro University, Örebro, Sweden

\section{Correspondence: \\ Karin Hugelius, $\mathrm{PhD}$ \\ Örebro University \\ School of Health Sciences \\ SE-701 82 Örebro, SWEDEN \\ E-mail: karin.hugelius@oru.se}

Conflicts of interests: Karin Hugelius was professionally involved within the described field operation, employed by a governmental authority. Lisa Kurland declares no competing interests.

Keywords: air medicine; consular evacuation disaster; crises management; evacuation; medevac

Received: September 24, 2021

Revised: November 3, 2021

Accepted: November 3, 2021

\section{doi:10.1017/S1049023X21001205}

(C) The Author(s), 2021. Published by Cambridge University Press on behalf of the World Association for Disaster and Emergency Medicine. This is an Open Access article, distributed under the terms of the Creative Commons Attribution licence (https:// creativecommons.org/licenses/by/4.0/), which permits unrestricted re-use, distribution, and reproduction in any medium, provided the original work is properly cited.
Event Type: Complex Emergency

Event Onset Date: August 16 to 28, 2021

Location of Event: Afghanistan (and the region)

Geographic Coordinates: Multiple

Dates of Observations Reported: August 24 to August 28, 2021

Response Type: Consular Repatriation and Humanitarian Evacuation

\begin{abstract}
Following the Taliban influx in August 2021, several Western countries repatriated nationals and evacuated others from Kabul Airport in Afghanistan. This report aimed to describe medical experiences from the consular repatriation and evacuation operation.

Memos from personal conversations with seven professionals involved in these operations formed the basis for this report.

Minor trauma, gastrointestinal symptoms, dehydration, fever, and mental distress were common. Bandages, oral rehydration solution, and the administration of paracetamol were needed, in addition to medical evaluation of acuity. In consular repatriation and humanitarian evacuations, medical attendance should be prioritized to manage medical needs of individuals being evacuated, but also from a public health perspective. The medical needs covered a broad specter of infection disease symptoms, trauma, and mental health problems among patients of all ages. Since the nature of consular repatriations and evacuations can be challenging from safety and infrastructural aspects, general medical emergency awareness with an ability to effectively evaluate and manage both somatic and mental health emergencies on the ground and in the air, among both children and adults, is needed.
\end{abstract}

Hugelius K, Kurland L. Medical experiences from a consular repatriation and evacuation operation from Afghanistan in August 2021: a field report. Prehosp Disaster Med. 2022;37(1):139-141.

\section{Background}

Following the Afghan peace process, the US and other military forces withdrew from Afghanistan in August 2021 after approximately 20 years of presence. The Taliban took over large parts of the Afghanistan territory and institutional leadership within a few days. The situation escalated quickly and many countries decided to repatriate their nationals as well as to conduct humanitarian evacuations of individuals. The term evacuation will be used throughout this report and includes both the consular repatriation and the humanitarian evacuation. The evacuations were conducted from the Kabul Airport, which was controlled by US forces. Airbridges were used to evacuate people to a transit site in the region, and thereafter to their final destination. The operation was massive: over 95 separate flights were conducted from Kabul to Europe. ${ }^{1}$ Since large-scale consular evacuations are uncommon events, ${ }^{2}$ this report aims to describe experiences from the medical perspective from the evacuation operations from Afghanistan in August 2021. All experiences and suggestions presented are the authors' own and do not reflect national or official opinions.

Method

This report is based on oral and written exchanges of experiences from seven professionals involved in the operation: two medical doctors, two nurses, one psychologist, and two diplomats, all representing Denmark, Germany, or Sweden, and were gathered during and after the operations by $\mathrm{KH}$, who participated in the operation. The professionals' experiences 


\begin{tabular}{|l|l|l|l|l|}
\hline & Extraction Phase & Transit Phase & $\begin{array}{l}\text { Transfer to Final } \\
\text { Destination }\end{array}$ & $\begin{array}{l}\text { Entrance in Final } \\
\text { Destination }\end{array}$ \\
\hline $\begin{array}{l}\text { Observed Symptoms and } \\
\text { Conditions }\end{array}$ & $\begin{array}{l}\text { Minor Trauma } \\
\text { Gastrointestinal Symptoms } \\
\text { Mental Distress }\end{array}$ & $\begin{array}{l}\text { Minor Trauma } \\
\text { Dehydration } \\
\text { Mental Distress }\end{array}$ & $\begin{array}{l}\text { General Fatigue } \\
\text { Fever } \\
\text { Gastrointestinal Symptoms } \\
\text { Motion Sickness } \\
\text { Mental Distress }\end{array}$ & Symptoms of Infection \\
\hline $\begin{array}{l}\text { Medical Equipment/ } \\
\text { Drugs Used }\end{array}$ & $\begin{array}{l}\text { Basic Life Support } \\
\text { Equipment }\end{array}$ & $\begin{array}{l}\text { Bandages } \\
\text { Oral Rehydration Solution } \\
\text { Paracetamol }\end{array}$ & $\begin{array}{l}\text { Food and Drinks } \\
\text { Oral Rehydration Solution } \\
\text { Paracetamol } \\
\text { Meclizine }\end{array}$ & None \\
\hline Medical Needs to be Met & $\begin{array}{l}\text { Safety and Security } \\
\text { Minor Injures } \\
\text { Advanced Life Support in } \\
\text { case of Major Events }\end{array}$ & $\begin{array}{l}\text { Ensuring All Persons were } \\
\text { "Fit for Flight" } \\
\text { Public Health Concerns }\end{array}$ & $\begin{array}{l}\text { Basic and Advanced } \\
\text { Medical Care to Avoid } \\
\text { Upscaled Situations } \\
\text { Onboard or Emergency } \\
\text { Landings due to Medical } \\
\text { Issues }\end{array}$ & $\begin{array}{l}\text { Public Health Concerns } \\
\text { Mental Health Concerns }\end{array}$ \\
\hline
\end{tabular}

Table 1. Summary of the Findings and Medical Needs

Hugelius @ 2022 Prehospital and Disaster Medicine

correspond to approximately 3,500 evacuees. No further information of the participants is presented to ensure protection of the informants' identity. Reflections were saved as memos that were analyzed, as inspired by thematic analysis, ${ }^{3}$ sorting the experiences and reflections by themes. Ethical approval was not needed since no personal information was used nor was allowed to be collected. An official from the Swedish Ministry of Foreign Affairs was invited to review the final draft due to the sensitive nature of the operations and to ensure that no information was shared which could harm the conducted or future operations. This official required no changes to be made to the manuscript.

\section{Observations}

The combination of a consular repatriation, humanitarian evacuation, and the necessity of military presence to enable access to the Kabul Airport led to many authorities and other actors being involved in the operation. This required close coordination and cooperation, both nationally and internationally, and both on strategic and operational levels. The legal status of the evacuees varied, from national residents (eg, people who had been on a temporary visit for longer or shorter periods of time) to quota refugees (eg, people who had been employed by Western entities and their families) and asylum seekers (eg, individuals considered to have a significant need for protection). Adults, infants, children, and elderly people were among the evacuees. Children traveling without any adult were present among the evacuated. A summary of the results is presented in Table 1 .

\section{Extraction Phase}

The extraction phase started when entering the Kabul Airport and lasted until the evacuee had been airlifted to a transit point. There was limited availability of medical assistance, in part due to security reasons and the chaotic circumstances. The conditions outside the terminal buildings were strained due to a constant threat to personal safety, no access or limited access to food and water, in addition to the heat. Most evacuees spent a few hours or less before being extracted once having gained access to the airport. During these hours, military medics and security officers serving within the airport and onboard the flights observed health care needs including minor trauma (eg, from being injured when trying to enter the airport, or by having been hit by someone or having fallen). These injuries were typically not serious. It is likely to assume that a natural triage occurred during the evacuation phase, excluding the overtly seriously injured or sick people. Many evacuees were, however, under severe distress. During the extraction flight, evacuees commonly showed symptoms of stress, motion sickness, or gastrointestinal infections, often presenting as anxiety, and vomiting.

\section{In-Transit Phase}

The time spent in transit/at the transit site, typically in a dedicated space within an airport, differed between a few hours up to 72 hours. The medical teams available at the transit site varied in size and composition, and not all transit sites had medical personnel at all. Basic medical care was provided on a request basis and there was no mandatory medical assessment of all evacuees. Cases of COVID-19 and measles were confirmed, leading to immediate contact with both local and receiving national health care authorities and inferred a delayed transfer to the final destination for these evacuees and their families. Additionally, several minor injuries including minor cuts, burns, blunt trauma, and sprains were reported. Some evacuees were in distress. However, no urgent needs for mental health interventions were reported. Many evacuees tried to contact relatives. However, most attempts failed due to weak or overloaded telephone systems. Access to baby diapers, sanitary napkins, potable water, and fruit was provided to all evacuees on site. Toys, games, or pen and pencils were also offered to activate the children.

\section{Transfer to Final Destination}

Some countries offered an official representative and some medical professionals onboard during the flight from the transit point to the final destination. Most evacuees were exhausted, both physically and mentally. It was therefore important to serve nonalcoholic drinks, snacks, and a hot meal during the longer flights. General fatigue, presented as a feeling of general weakness, feeling sick, or dizziness, was common. Fainting, headache, fever, panic attacks, nausea, and joint or muscle pain were other common conditions 
requiring medical attention. Symptoms of COVID-19 (fever, cough, and nausea) or diarrhea or vomiting were also common. Distress could present with somatization (eg, hyperventilation) or sadness. A family consisting of eight persons all showed symptoms of the chickenpox midst flight, requiring specific attention when entering the receiving country.

\section{Entrance to Final Destination}

All countries represented in this report had procedures in place upon arrival to the final destination. However, these procedures varied due to the legal status of the evacuee (ie, being a repatriated national, quota refugee, or asylum seeker). Most countries had medical teams and representatives from social services available air-side or land-side at the airport port of entry, with the objective to observe the evacuees for signs of severe disease or communicable disease. Some countries conducted a mandatory self-health declaration, a brief clinical assessment, or mandatory COVID-19 tests of all evacuees, while some used such procedures only for some evacuees depending on the evacuee's legal status. There was a concern that the nationals that had not been in their countries of citizenship for many years would not commit to, or understand, the general advice for travelers (eg, the need to test for COVID-19 or to isolate for a period as required by the national health authorities). In addition, health care professionals were concerned that medical issues observed and treated during the evacuation, including communicable disease symptoms and mental health issues, would not be followed up by national health care services.

\section{Discussion}

The operation included both the repatriation of nationals and evacuation of refugees and asylum seekers (ie, people of all ages and a wide range of somatic and mental health needs). Medical competence was needed in all phases of the operations. The medical incidents described in the current report occurred mainly during the transfer flight, despite the evacuees having been assumed to be "fit for flight." The operations were not aimed at evacuating injured people, per se, but there was no structured medical assessment before the extraction. The same is described in prior repatriation operations. ${ }^{4}$ In addition to pre-flight conditions, the lowered oxygen level, vibrations, noise, limited space, and for many people, unknown environment onboard an aircraft may add extra strain to both psychical and mental well-being. Therefore, the presence of medical professionals onboard is an important part of evacuation operations, both to manage medical emergencies and to add a sense of safety for both the evacuees and the flight crew.

Several evacuees showed symptoms of distress, but none were reported to be in such a severe psychiatric condition as to not be able to care for him/herself. The level of uncertainty and distress could be reduced by providing clear and repeated information during the evacuation. ${ }^{5}$ Interpreters or professionals speaking the same languages as the evacuees are essential to enable this. Enabling contact with family members should also be prioritized, since contact with family members is a core element in psychosocial support. ${ }^{6}$ Additionally, mental health problems that were present before the evacuation are likely to be exacerbated and may also require specific consideration to enable safe travel. ${ }^{7}$

The evacuation from low- or middle-income countries requires knowledge of migration health and travel medicine. Outbreaks of highly contagious diseases (eg, measles) requires planning to detect infected individuals before and during the evacuation and to take appropriate measures when arriving to the final destination. This potential risk to public health needs to be addressed. It is of importance to establish routines for how medical personnel should report to colleagues in other parts of the evacuation operation. Processes for medical screening and health care when arriving at the final destination require consideration when receiving evacuees that legally answer to diverse legal statuses. Especially important are strategies to follow up communicable diseases and mental health concerns.

\section{Limitations}

The first and obvious limitation of this report is the lack of medical records or other objective data. However, given the circumstances of the operations, no such data were available nor was data gathering allowed. Therefore, presenting professionals experiences, personal conversations, and memos was a pragmatic approach to gather, analyze, and disseminate these experiences. Ethical permission was not obtained for this study since no sensitive data from individuals or medical records were used. However, consular repatriations and/or humanitarian evacuations might require that detailed reports and observations on procedures, individuals involved, or diplomatic methods are not shared. Therefore, no details on such matters have been described in this study, even if that limits the possibility to present a complete picture of the operations. In the future, processes to gather data should be planned for and included to enable research.

\section{Conclusions and Recommendations}

Medical concerns should be carefully analyzed, from both an individual and public health perspective, in all phases of a consular repatriation and humanitarian evacuation. The medical interventions covered a broad spectrum from less serious to more serious conditions, including both somatic and mental health problems among people of all ages. Therefore, health care professionals involved in operations such as these need a broad and general medical knowledge and experience of managing both everyday problems and medical emergencies on the ground and in the air and need to be prepared to work under spartan, and at times, hostile circumstances.

\section{References}

1. Directorate General European Union Civil Protection and Humanitarian Aid Operations (ECHO). Daily map dated 03/09/21. https://erccportal.jrc.ec.europa.eu/ ECHO-Products/Maps\#/maps/3833. Accessed September 3, 2021.

2. Tindall K, Hart, P. Evaluating government performance during consular emergencies: toward an analytical framework. Policy Soc. 2011;30(2):137-149.

3. Braun V, Clarke V. Using thematic analysis in psychology. Qual Res Psychol. 2006;3(2):77-101.

4. Marmor M, Goldstein L, Levi Y, et al. Mass medical repatriation of injured civilians after terrorist attack in Mombassa, Kenya: medical needs, resources used, and lessons learned. Prehosp Disaster Med. 2005;20(2):98-102.

5. Peters A, McEwen BS, Friston K. Uncertainty and stress: why it causes diseases and how it is mastered by the brain. Prog Neurobiol. 2017;156:164-188.

6. Hobfoll SE, Watson P, Bell CC, et al. Five essential elements of immediate and midterm mass trauma intervention: empirical evidence. Psychiatry. 2007;70(4):221-242.

7. Felkai PP, Marcolongo T, Van Aswegen M. Stranded abroad: a travel medicine approach to psychiatric repatriation. J Travel Med. 2020;27(2). 